\title{
Palaemon monsdamarum n. sp. (Crustacea, Decapoda, Palaemonidae) from the late Miocene of Mondaino (Rimini, Emilia-Romagna, Italy)
}

\author{
Giovanni Pasini ${ }^{1}$, Alessandro Garassino ${ }^{2 *}$
}

\begin{abstract}
We report Palaemon monsdamarum n. sp. (Crustacea, Decapoda, Palaemonidae) from the tripoli of the Messinian (upper Miocene) of Mondaino (Rimini, Emilia-Romagna, Italy). The presence of a new caridean species expands the scarce knowledge on the distribution and environmental range for the genus, usually scarcely reported in the worldwide Cenozoic fossil record. This is the first report of a carideans from the Miocene of Italy.
\end{abstract}

Key words: Crustacea, Decapoda, Palaemonidae, Miocene, Italy.

Riassunto - Palaemon monsdamarum n. sp. (Crustacea, Decapoda, Palaemonidae) del Miocene superiore di Mondaino (Rimini, EmiliaRomagna, Italia)

Viene descritto Palaemon monsdamarum n. sp. (Crustacea, Decapoda, Palaemonidae) del tripoli Messiniano (Miocene superiore) di Mondaino (Rimini, Emilia-Romagna, Italia). La presenza di una nuova specie di carideo amplia le scarse conoscenze sulla distribuzione temporale e ambientale dei rappresentanti fossili di questo genere raramente segnalato nel record fossile del Cenozoico. Si tratta della prima segnalazione di un carideo nel Miocene italiano. Italia

Parole chiave: Crustacea, Decapoda, Palaemonidae, Miocene,

\section{INTRODUCTION AND GEOLOGICAL SETTING}

Mondaino (Rimini, Emilia-Romagna) is located in the south-central Appennini Mountains (NE Italy) $\left(43^{\circ} 51 ' 21.24\right.$ 'N, $\left.12^{\circ} 40^{\prime} 17.33^{\prime \prime} \mathrm{E}\right)$. In the surronding area some Messinian (upper Miocene) deposits crop out, distinguished by the presence of tripoli levels at the bottom of the evaporitic sequence known as "Formazione Gessoso Solfifera" (Bedini et al., 1986). These laminated tinny white to yellow-grey levels are highly fossiliferous,

\footnotetext{
${ }^{1}$ Via Alessandro Volta 16, 22070 Appiano Gentile (CO), Italia.

E-mail: juanaldopasini@tiscali.it

${ }^{2}$ Sezione di Paleontologia degli Invertebrati, Museo di Storia Naturale, Corso Venezia 55, 20121 Milano, Italia.

* Corresponding author: alessandro.garassino@comune.milano.it; alegarassino@gmail.com

(C) 2018 Giovanni Pasini, Alessandro Garassino

Received: 9 August 2017

Accepted for publication: 22 August 2017
}

including mainly a well-studied marine fish fauna (Sorbini \& Tirapelle Rancan, 1980; Bedini et al., 1986; among others), whereas the associated fauna is scarce, including invertebrates, such as regular echinoids and flying insects (Coleoptera), the latter studied by Bonomi (1896), vertebrates (incomplete birds), and terrestrial plant remains. Among crustaceans only some rare ostracods were reported (see Bedini et al., 1986).

The fossil ichthyofauna assemblage is peculiar of subtropical waters, with the presence of both colder and warmer waters species. At generic level the Mondaino fish assemblage shows affinities with the Plio-Pleistocene and extant Mediterranean ichthyofauna. According to Bedini et al. (1986) the marine tripoli depositional basin suggests a depth between 100 and $200 \mathrm{~m}$., lacking currents and being poorly oxygenated at the bottom, locatd not very far from the coastline.

The studied specimen was found from a tripoli level, associated with some indeterminate poorly preserved small fishes.

This is the first report of a decapod crustacean from the late Miocene tripoli of Italy.

\section{MATERIALS AND METHODS}

One complete specimen in lateral view, flattened and slightly compressed transversally, preserved on a small tinny slab of laminated yellow-grey tripoli level. Due to the delicate nature of the studied specimen, it was fixed by a film of polyvinilic acetate for study and preservation. The studied specimen was investigated by natural and UV illimination in order to emphasize detailed parts of the delicate structures. Unfoturnately UV method was unsatisfactory not emphasizing some characters due to the sediment not particularly sensitive to UV illumination.

The specimen is housed in the palaeontological collections of the Museo di Storia Naturale di Milano (MSNM).
Abbreviations
lcxp: carapace length
mpx3: third maxilliped
P1-P5: pereiopods 1-5
s1-s6: pleonal somites 1-6
wcxp: carapace width 


\section{SYSTEMATIC PALAEONTOLOGY}

Infrorder Caridea Dana, 1852

Superfamily Palaeomonoidea Rafinesque, 1815

Family Palaemonidae Rafinesque, 1815

Genus Palaemon Weber, 1795

Type species: Palaemon adspersus Rathke, 1837, by original designation.

Fossil species: Palaemon antonellae Garassino \& Bravi, 2003; P. exul Fritsch, 1872; P. monsdamarum n. sp. (this study); P. mortuus Smirvov, 1929; P. vesolensis Bravi, Coppa, Garassino \& Patricelli, 1999.

\section{Palaemon monsdamarum n. sp. (Fig. 1)}

Diagnosis: Carapace subrectangular; rostrum elongate, with single tip and 3-4 dorsal granule-shaped spines; P1-P2 chelate; uropodal exopod without diaeresis.

Etymology: from Mons Damarum (= Fallow's deer mount), ancient name of Mondaino, fossiliferous locality where the studied specimen was collected.

Holotype: MSNM i29208.

Type locality: Mondaino (Rimini, Emilia-Romagna).

Geological age: late Miocene (Messinian).

Material and measurements: One specimen in lateral view (lcxp: $7 \mathrm{~mm}$, excluding rostrum; wcxp: 4 $\mathrm{mm}$ ).

Description: Small-sized caridean with thin, smooth exoskeleton. Carapace - Carapace subrectangular, elongate, narrowing slightly anteriorly due to slight curvature of the ventral margin; dorsal margin nearly straight; ridged posterior margin, gently sinuous and slightly concave in upper third; ventral margin curvilinear more inflated posteriorly; dorsal margin with thin longitudinal dorsal carina extending into long pointed, dorsally serrate rostrum; rostrum with a short rim of very small-sized granular suprarostral teeth decreasing in size towards the tip; ventral margin not observable; ocular incision narrow, shallow; antennal spine present; hepatic spine absent; no traces of grooves, carinae, or spines on carapace lateral surface. Cephalic appendages - Cephalic appendages incomplete; antennulae triflagellate; laminar scaphocerite present. Pleon - Pleon with s1, s3-s5 subtriangular ventrally, pointed and similar in length; s2 pleura subrounded, partially overlapping those of s1 and s3; s6 subrectangular, elongate, with curved ventral margin, narrowing posteriorly, longer than the others; anterior margin of s1, s3-s5 slightly sinuous; s4-s5 posteriorly projecting; tail fan longer than telson; triangular telson, poorly preserved; uropodal exopod without diaeresis, with thin longitudinal medial carina. Thoracic appendages - Mpx3 short, narrow, and spineless; P1-P5 similar in length; P1-P2 chelate; P1-P2 chelae very small and thin; P3-P5 achelate. Pleonal appendages - Pleopods not preserved.

Discussion. The fossil record of carideans from the Cenozoic deposits are very scarce. According to Schweitzer et al. (2010) only four genera are known to date from the Cenozoic, Bechleja Houša, 1956, Propalaeomon Woodward, 1903, Pseudocaridinella Martins-Neto \& Mezzalira, 1991, and Palaemon Weber, 1795.
Bechleja Houša, 1956 is known with four species, as follows: B. inopinata Feldmann, Grande, Birkhmer, Hannibal \& McCoy, 1981 (Eocene, Green River Fm., Wyoming, USA); B. bahiaensis (Beurlen, 1950) and B. robusta Martins-Neto \& Mezzalira, 1991 (Oligocene, Brazil); $B$. inopinata Houša, 1956 (Oligocene-Miocene, Czech Republic) (Beurlen, 1950; Houša, 1956; Feldmann et al., 1981; Martins-Neto \& Mezzalira, 1991). According to Houša (1956) and Martins-Neto \& Mezzalira (1991) the main diagnostic characters for the genus are the dorsally and ventrally serrate rostrum, a single filament antennule (instead two filament antennule according to Feldmann et al., 1981), $\mathrm{P} 1$ with short chela, and $\mathrm{P} 2$ with elongate chela. However, we raise doubt about the diagnosis of the genus. Indeed, Houša (1956) described B. inopinata as a palaemonid with dorsally serrate rostrum, Feldmann et al. (1981) reported B. rostrata as a palaemonid with ventrally serrate rostrum, whereas Martins-Neto \& Mezzalira described $B$. robusta as a palaemonid with short spineless rostrum. Though these characters fit more or less with the diagnosis made by the above-mentioned authors, it would be important to revise the type species (B. inopinata) of Bechleja in order to establish its real diagnostic characters, avoiding to consider it as a "basket" genus.

Though the studied specimen shares two diagnostic characters for the genus, such as the dorsally serrate rostrum and the P1 with short chela, we can exclude its belonging to this genus not only for the triflagellate antennule, but also because Bechleja is known as freshwater genus, whereas the studied specimen inhabited a stricly marine environment.

Propalaeomon Woodward, 1903 is known with two species, as follows: P. osborniensis Woodward, 1903 (late Eocene, Isle of Wight, Great Britain) and P. longispinata Martins-Neto \& Mezzalira, 1991 (Oligocene, Brazil) (Woodward, 1863; Woods, 1925; Martins-Neto \& Mezzalira, 1991). Woodwad (1903) described also P. minor, including small specimens from the late Eocene of Isle of Wight that he considered more convenient to treat as a distinct species though they could be juvenile forms of $P$. osborniensis. According to Gaudant \& Quayle (1988) P. minor has to be considered as a juvenile synonymous with the type species $P$. osborniensis. According to Gaudant \& Quayle (1988) the main diagnostic characters for the genus are the dorsally serrate rostrum with bifid tip, short hepatic spine, P1 and P2 chelate with P2 longer than P1.

Based upon the main characters for the genus, we can exclude the belonging of the studied specimen to Propalaemon in having a rostrum with a single tip and lack of hepatic spine.

Pseudocaridinella Martins-Neto \& Mezzalira, 1991 is known with two species from the Oligocene of Brazil, as follows: P. tremembeensis (Beurlen, 1950) and $P$. roxoi (Beurlen, 1950) (Beurlen, 1950; Martins-Neto \& Mezzalira, 1991). According to Martins-Neto \& Mezzalira (1991) the main diagnostic characters for the genus are: rostrum smooth, $\mathrm{P} 2$ carpus excavated, and moderate dilatation of s2 base.

Based upon the main characters for the genus, we can exclude the belonging of the studied specimen to Pseudocaridinella in having dorsally serrate rostrum. 

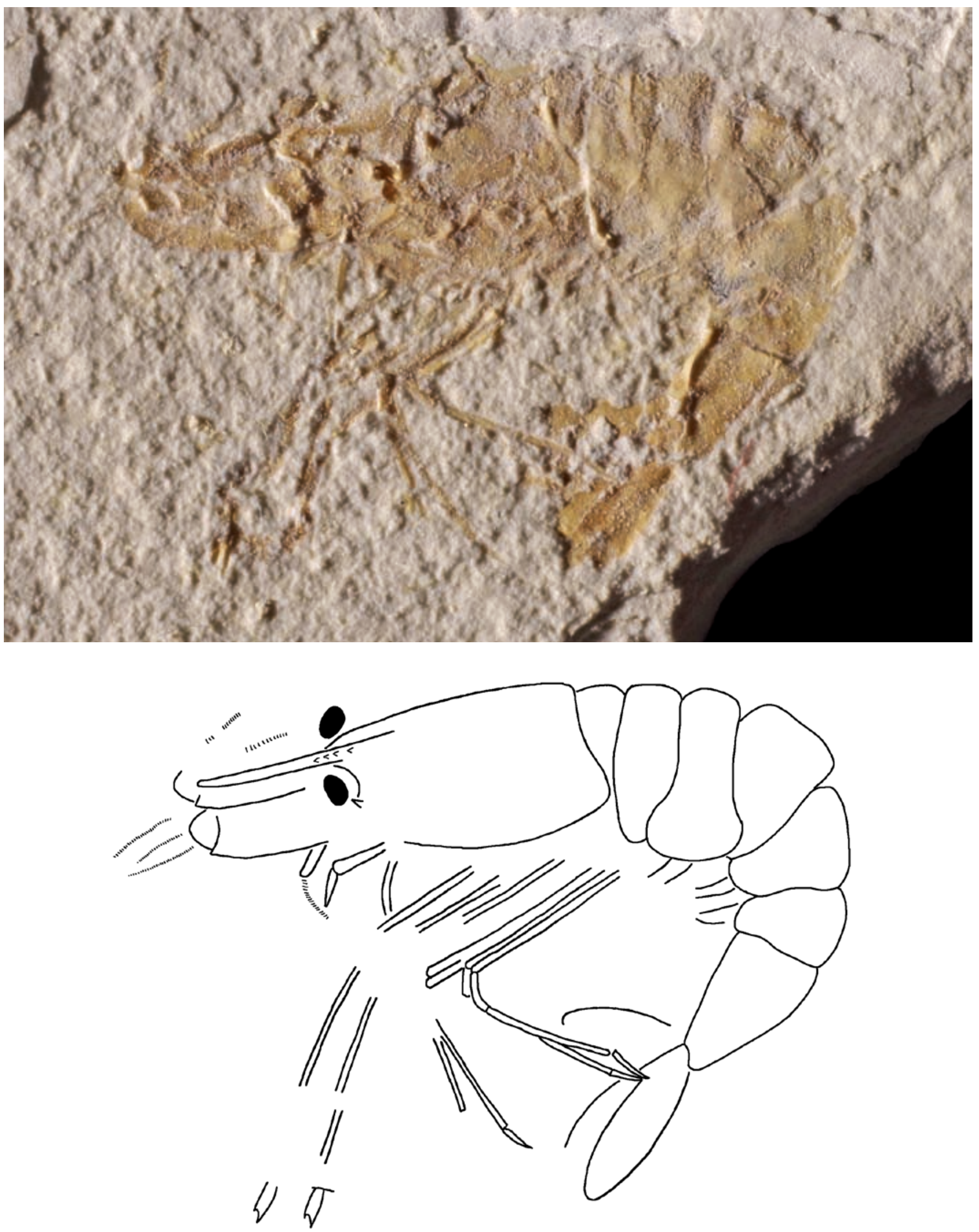

Fig. 1 - Palaemon monsdamarum n. sp., Holotype, MSNM i29208. A) General view (x 5.7). B) Line drawing. 
According to Schweitzer et al. (2010) Palaemon Weber, 1795 is known with six species, as follows: $P$ vesolensis Bravi, Coppa, Garassino \& Patricelli, 1999 and $P$. antonellae Garassino \& Bravi, 2003 (Late Cretaceous, Italy); B. bahiaensis Beurlen, 1950 (Oligocene, Brazil); P. mortuus Smirnov, 1929 (Miocene, Caucasus), P. fabricii Michelotti, 1861 (Miocene, Italy); and P. exul Fritsch, 1872 (Miocene, Boemia) (Michelotti; 1861; Fritsch, 1872; Smirnov, 1929; Beurlen, 1950; Bravi et al. 1999; Garassino \& Bravi, 2003). However, according to Martins-Neto \& Mezzalira (1991) P. bahiaensis has to be considered a species of Bechleja, whereas $P$. fabricii has to be considered a species of Penaeus vanzii Beschin \& Garassino, 1999 according to Beschin \& Garassino (1999). Finally, Houša (1956) attested that $P$. exul should not be included in this genus "because it differs from it by several important characters" that, however, that author did not clarify why. According to Glaessner (1969) the main diagnostic characters for the genus are elongate dorsally and ventrally serrate rostrum; antennal and branchiostegal spines present; hepatic spine absent; antennule triflagellate; and telson with four apical spines.

The studied specimen, sharing some diagnostic characters for the genus, such as the dorsally serrate rostrum, the antenal spine, the lack of the hepatic spine, and the antennule triflagellate, is assigned to Palaemon.

The genus is known from the Miocene fossil record with two species, P. mortuus and P. exul. Palaemon monsdamarum n. sp. differs from the type species, P. mortuus, in having a rostrum with 3-4 granule-shaped dorsal spines (vs. rostrum with 4-5 strong dorsal spines in P. mortuus). The bad quality of the drawing reported by Fritsch (1872) of $P$. exul hampers the comparison with the new species. Indeed the rostrum appears broken and the carapace seems to have a complex groove and carina system. As already pointed out by Houša (1956) a new genus should be erected to accomodate this species.

Based upon these observation, P. monsdamarum n. sp. is the first report of carideans from the Miocene of Italy.

\section{Acknowledgements}

We wish to thank Giorgio Teruzzi, Sezione di Paleontologia degli Invetebrati, Museo di Storia Naturale, Milano (Italy), for the photos of the studied specimen. Moreover we thank Francisco J. Vega, Instituto de Geología, UNAM, Cuidad Universitaria, Coyoacán (Mexico) and Günter Schweigert, Staatliches Museum für Naturkunde, Rosenstein 1, Stuttgart (Germany), for criticism and careful review.

\section{REFERENCES}

Bedini E., Francalacci P. \& Landini W., 1986 - I pesci fossili del Miocene superiore di Montefiore Conca e Mondaino (Forli). Memorie del Museo Civico di Storia Naturale di Verona (2a Serie), Sezione scienze della Terra, 3.

Beschin C. \& Garassino A., 1999 - Penaeus vanzii n. sp. e Penaeus sorbinii n. sp. (Crustacea, Decapoda) dell'Oligocene della Valle del Ponte (Laverda) e di Salcedo (Vicenza, N. Italia). Atti della Società italiana di Scienze naturali e del Museo civico di Storia naturale in Milano, 140 (2): 189-208.

Beurlen K., 1950 - Alguns restos de Crustáceos Decápodes d'água doce fósseis no Brasil. Anais da Academia Brasiliera de Ciencias, 22 (4): 453-459.

Bonomi I., 1896 - Contributo alla conoscenza dell'ittiofauna miocenica di Mondaino. Rivista Italiana di $\mathrm{Pa}$ leontologia, 2 (4): 129-239.

Bravi S., Coppa M.G., Garassino A. \& Patricelli R., 1999 Palaemon vesolensis n. sp. (Crustacea, Decapoda) from the Plattenkalk of Vesole Mount (Salerno, S Italy). Atti della Società italiana di Scienze naturali e del Museo civico di Storia naturale in Milano, 140 (2): 141-169.

Feldmann; R.M., Grande L., Birkhmer C.P., Hannibal J.T. \& McCoy D.L., 1981 - Decapod fauna of the Green River Formation (Eocene) of Wyoming. Journal of Paleontology, 55 (4): 788-799.

Fritsch A., 1872 - Ueber Palaemon exul, eine neue Crustacee aus dem Polierchiefer von Kutschlin bei Bilin in Böhmen. Sitzungsberichte der Königlichen Böhmischen Gesellschaft der Wissenschaften, 1872: 37-38.

Garassino A. \& Bravi S., 2003 - Palaemon antonellae n.sp. (Crustacea, Decapoda, Caridea) from the Lower Cretaceous "Platydolomite" of Profeti (Caserta, S Italy). Journal of Paleontology, 77 (3): 589-592.

Gaudant J. \& Quayle W.J., 1988 - New palaeontological studies on the Chapelcorner Fish Bed (Upper Eocene, Isle of Wight). Bulletin of the British Musem (Natural History), Geology, 44: 15-39.

Glaessner M., 1969 - Decapoda. In: Treatise on Invertebrate Paleontology, R (4) (2): R400-R533, R626-R628. Moore R.C. (ed.). Geological Society of America, Boulder, Colorado, and University of Kansas Press, Lawrence, Kansas.

Houša V., 1957 [imprint 1956]. Bechleja inopinata n. g., n. sp., ein neuer Krebs aus dem böhmischen Tertiär (Decapoda, Palaemonidae). Sborník Úst redního Ústavu Geologické, (Oddil Paleontologický), 23: 365-377.

Martins-Neto R.G. \& Mezzalira S., 1991 - Revisão dos Palemonídeos Terciários Brasileiros (Crustacea, caridea) con Descrição de Novos Taxa. Anais da Accademia Brasileira de Ciências, 63 (4): 361-367.

Michelotti G., 1861 - Études sur le Miocène Inférieur de l'Italie septentrionale. Leyden.

Schweitzer C.E., Feldmann R.M., Garassino A., Karasawa H., Schweigert G., 2010 - Systematic list of fossil decapod crustacean species. Crustaceana Monographs, 10: 1-222.

Sorbini L. \& Tirapelle Rancan R., 1980 - Messinian fossil fish of the Mediterranean. Palaeogeography, Palaeoclimatology, Palaeoecology, 29 :143-154.

Smirnov W., 1929 - Decapoda der Fischschichten am Schwarzen Flusse von der Stadt Wladikawkas. Arbeiten der Nord-Kaukasischen Assoziation Wissenschaftlicher Institute, 59: 1-48.

Woods H., 1925-1931 - A monograph of the fossil macrurous Crustacea of England. Palaeontographical Society, London: 1-122.

Woodward H., 1903 - On some Fossil Prawns from the Osborne Beds of the Isle of Wight. The Geological Magazine, 10 (4): 97-99. 